\title{
A RESPONSABILIDADE SOCIAL DO MAGISTRADO E A PROTEÇÃO DA DEMOCRACIA
}

\section{THE SOCIAL RESPONSABILITY OF THE MAGISTRATE AND THE PROTECCION OF DEMOCRACY}

\author{
${ }^{1}$ José Renato Gaziero Cella \\ ${ }^{2}$ Gustavo Wentz
}

\section{RESUMO}

O protagonismo judicial é tema que gera preocupações. Uma das formas mais eficazes de limitálo é pelo controle social dos atos dos magistrados, que detêm uma grande responsabilidade social ao decidir. Não restam dúvidas de que a sociedade é a maior interessada na estruturação de um Poder Judiciário efetivo e independente e balizadora dos seus ideais. Dessa forma, o magistrado deve ser visto como uma agente promocional da democracia. Por essas razões, o presente artigo, por meio do método hipotético-dedutivo, traz como hipótese a possibilidade da responsabilização civil do magistrado cuja decisão tiver ultrapassado limites razoáveis da aplicação do direito.

PALAVRAS-CHAVE: Democracia; Protagonismo Judicial; Responsabilidade Social do Magistrado

\begin{abstract}
One of the most effective ways to limit it is the social control of the acts of judges, which have a great social responsibility to decide. There is no doubt that society is most interested in structuring an effective judiciary and independent ideals. Thus, the magistrate should be seen as a promotional agent of democracy. For these reasons, this article, through the hypotheticaldeductive method, it brings the hypothesis the possibility of the magistrate's civil liability whose decision has exceeded reasonable limits the application of the law.
\end{abstract}

KEYWORDS: Democracy; Judicial Role; Social Responsibility Of The Magistrate

\footnotetext{
${ }^{1}$ Doutor em Filosofia e Teoria do Direito pela Universidade Federal de Santa Catarina - UFSC, Santa Catarina, SC, (Brasil). Mestre em Direito do Estado pela Universidade Federal do Paraná - UFPR, Paraná, PR, (Brasil). Professor do Programa de Pós-Graduação (Mestrado) em Direito da Faculdade Meridional - PPGD/IMED, Rio Grande do Sul, RS, (Brasil).E-mail: cella@cella.com.br.

${ }^{2}$ Graduado em Ciências Jurídicas e Sociais - Universidade de Passo Fundo - UPF, Rio Grande do Sul, RS, (Brasil). Especialista em Direito e Processo Civil - UPF. Mestrando em Direito pela Faculdade Meridional - IMED, Rio Grande do Sul, RS, (Brasil). Beneficiário de Taxa de Mestrado PROSUP-CAPES. E-mail: gustavowentz@hotmail.com.
} 


\section{INTRODUÇÃo}

É tênue a linha que divide a regular atuação política e social dos agentes públicos, promotora da democracia, do ponto em que passa a desrespeitá-la, isso porque é muito grande o poder de mando e decisão que concentram em suas mãos. Contudo, esse verdadeiro poder, que é democrático em sua origem, deveria sempre ser exercido de forma a proteger e desenvolver a democracia, bem como para incentivar o desenvolvimento da nação, tendo em vista os preceitos básicos da separação e do respeito entre as três funções e o dever de prestar contas para a sociedade organizada.

Mas, infelizmente, o que se tem presenciado nas últimas décadas é uma busca frenética e inconsequente por mais poder e pelo protagonismo das ações em detrimento não apenas dos demais agentes públicos, mas também das próprias instituições. Em especial, pode-se citar a condição dos juízes que tomaram para si o papel de heróis sociais, protegidos por seus escudos constitucionais e aproveitando-se dos vazios criados tanto pela profunda crise de confiança por que passam os Poderes Legislativo e Executivo no Brasil quanto pela repetição de legislações abertas e imprecisas, que acabam por abrir um gigantesco leque para a interpretação.

Dessa forma, o presente trabalho, que segue o método hipotético-dedutivo, tem por objetivo pesquisar (objetivo geral) a intrínseca relação entre a atuação do magistrado e a democracia, a vista da sua responsabilidade social. Já os objetivos específicos podem ser delimitados como: (a) analisar a responsabilidade social do magistrado e as suas possíveis consequências; (b) analisar e contextualizar o protagonismo judicial, apontando as suas consequências para a democracia; e (c) estabelecer uma relação entre a responsabilidade social do magistrado, o protagonismo judicial e a democracia, de forma a compreender a atual fase de desenvolvimento da democracia nacional.

Para tanto, ao final desse trabalho uma pergunta deve restar respondida: a responsabilidade social do magistrado se configura como ferramenta de proteção e promoção a democracia, enquanto o protagonismo do magistrado, ao contrário, enfraquece a democracia nacional? Para que seja possível responder a essa pergunta dois grandes e tortuosos caminhos precisam necessariamente ser percorridos. $\mathrm{O}$ primeiro, considerando a responsabilidade social do magistrado como a principal ferramenta de controle da sua atuação, e de outro lado considerando o protagonismo do magistrado como um instrumento anômalo, criado no seio do próprio sistema judiciário, de forma não democrática. Já o segundo caminho considera importante, mas não 
fundamental, a responsabilidade social do magistrado e entende o protagonismo judicial como uma resposta a crise dos demais Poderes, o que, por via reflexa o legitima, e, portanto, encontraria ai a sua fundamentação democrática.

\section{RESPONSABILIDADE SOCIAL DO MAGISTRADO}

A atuação do magistrado ganha cada vez mais importância tanto no cenário político quanto no cenário social brasileiro. Isso porque já não se sustenta firme a clássica separação entre as funções e o escalonamento das competências, dada a severa crise vivenciada pelos demais Poderes instituídos. Assim, um específico ramo da responsabilidade do magistrado merece maior atenção e um maior aprofundamento da sua base de estudos, qual seja a responsabilidade social dos magistrados, bem como a análise das suas consequências (sejam elas positivas ou negativas) para o desenvolvimento da democracia nacional.

A responsabilidade social do juiz engloba todos aqueles casos em que o magistrado emprega de forma abusiva os poderes que lhe são concedidos em razão do próprio cargo, bem como para todos aqueles outros casos em que se mantém inerte, mesmo quando deveria necessariamente agir. Porém, são casos específicos, em que não é possível a aplicação de sanções diretamente previstas na legislação (AGUIAR JR.: 2000, p. 12). São casos em que o magistrado, ao agir (ou ao deixar de agir) acaba não observando os mínimos preceitos legais.

Portanto, essa modalidade de responsabilização encontra-se incerta no estrito âmbito do exercício da jurisdição (atuação regular do magistrado), sem que a legislação pátria em vigor reconheça algum tipo de punição jurídica ou administrativa ao magistrado que use mal ou deixe de usar o seu poder de forma correta ou meramente adequada. Jamais será possível confundi-la com as modalidades de responsabilização civil (jurídica) ou política do magistrado, mesmo que nesses casos a aplicação de sanções seja quase nula em nosso País, o que decorre tanto da fragilidade das legislações sobre o tema quanto do corporativismo que impede a sua aplicação plena (juízes julgando juízes) (AGUIAR JR.: 2000, p. 12). Ou seja, aqui a única punição imposta ao magistrado é a própria reprovação social de seus atos. Nesta modalidade de responsabilização, a atuação do magistrado é verificada pela critica da sociedade, sem que haja qualquer tipo de punição.

Em outras palavras, a responsabilidade social do magistrado impõe a existência de uma relação verdadeiramente social entre a atuação do magistrado e as suas consequências para a sociedade, em que se destaca a importância da correta fundamentação das decisões (tema 
complexo e que merece maior estudo no Brasil), isso porque as razões de uma sentença, por mais que vinculem (processual e materialmente) apenas as partes litigantes, são dirigidas a todos os cidadãos. Pois é através da fundamentação das decisões (e não somente pelo decidir - do dispositivo da sentença) que o magistrado apresenta novos limites e novos entendimentos sobre a lei. Ademais, fornece tanto aos contendores quanto aos estudiosos a possibilidade de contrastar e analisar os diversos julgados, de forma a tirar deles valiosas lições na busca de futuras soluções a seus litígios. Mais do que isso, é uma forma possível de ajudar a elidir a arbitrariedade dos julgadores e de corrigir eventuais distorções nas interpretações jurídicas (CYRILLO DA SILVA: 2002, p. 85).

Em outros países, que assim como o Brasil se guiam por modelos democráticos, pode-se encontrar outras formas de controle social da atuação do magistrado, até mesmo mais eficazes, mas para os fins que se propõem este estudo, a analise será concentrada apenas no modelo que melhor se enquadra a realidade nacional. Assim, o que está proposto à discussão é a exposição do comportamento do magistrado à crítica social, em especial pelos meios de comunicação de massa e a crítica doutrinária especializada. Essas duas ferramentas de análise da conduta do magistrado são eficazes apenas em países em que os cidadãos gozam efetivamente de grande liberdade de expressão e de pensamento (CAPPELLETTI: 1989, p. 47).

Nesse contexto, a publicidade do processo e das decisões é o ponto crucial para que se possa exercer o verdadeiro controle da atuação do magistrado. Da mesma forma, a publicação e a divulgação das razões dos votos divergentes dos órgãos colegiados (comum no contexto brasileiro, mas ausente em muitos países democraticamente abertos), apresentam relevante importância. Manter sob sigilo os votos divergentes (seja diante de aspectos burocráticos ou mesmo com o pretexto de preservar a ordem nacional, manter a estabilidade e a segurança jurídica) acaba por tornar-se um grandioso obstáculo não apenas para a responsabilização social, mas também para aplicação de penas atinentes tanto a responsabilidade jurídica quanto da responsabilidade política dos juízes (CAPPELLETTI: 1989, p. 48). É por meio do conhecimento desenvolvido pelo voto divergente que se torna possível a correta análise do voto vencedor dos órgãos colegiados. Certamente, o voto divergente surge ou de um entendimento diverso quanto à legislação aplicável ao caso, ou mesmo quanto a uma situação fática pontual desconsiderada pelos demais julgadores.

Mesmo reconhecida a importância do tema e a seu papel fundamental na promoção da democracia, ainda há um grande embate a ser travado quanto aos princípios constitucionais: de um lado se tem o dever de prestar contas, dever este de cunho puramente democrático e imposto Revista de Teorias da Justiça, da Decisão e da Argumentação Jurídical e-SSN: 2525-9644|Curitiba|v.2|n. 2|p.117-132| Jul/Dez. 2016. 
a todos aqueles que, de uma forma ou de outra, detêm em suas mãos o poder (não só magistrados, mas agentes públicos vinculados a todos os Poderes), e de outro lado, tem-se todo o meandro de garantias de independência do Poder Judiciário e de seus integrantes (aplicáveis em especial aos magistrados). Diante dessa dicotomia, muitas vezes a crítica à atividade judiciária (e em especial a conduta do juiz) é sujeita a restrições, até mesmo como forma de evitar pressões indevidas direcionadas a pessoa do magistrado, que assim poderia ver-se coagido a julgar conforme essas pressões. Isso ocorre até mesmo em países em que a liberdade de expressão e de opinião se encontra em um alto patamar dentro da escala de princípios fundamentais e democráticos (CAPPELLETTI: 1989, p. 49).

E aqui se vê mais uma característica importante para a efetividade da responsabilidade social dos atos do magistrado, que passa pela criação de uma cultura democrática dos magistrados, que devem aprender a ouvir as críticas da sociedade, de forma a aprimorar o seu trabalho, tornando-os capazes de entregar à sociedade um trabalho de qualidade.

Dessa forma, pode-se concluir que, em não havendo previsão legal para sanção jurídica ao magistrado quando este deixa de fazer o correto uso de seus poderes, está-se diante de um caso de responsabilidade social (e não jurídica ou política). Esta responsabilidade decorre da relação direta entre o magistrado e a sociedade, e que se manifesta de várias maneiras, constituindo-se em verdadeiro modelo de controle difuso da atuação do Poder Judiciário. Mas para que realmente ocorra esse tipo de controle, é necessário que se garanta a publicidade das decisões, que a sociedade se mantenha organizada e disposta a participar e promover o debate de avaliação dessas decisões (AGUIAR JR.: 2000, p. 13).

Essa é uma proposta para se aprimorar a garantia de um viés mais democrático do controle de atuação da magistratura, pois possibilitaria um maior exercício, pela sociedade, de controle externo sobre o Poder Judiciário. Importante mencionar que esse controle jamais será capaz de mudar, por si só, um comando sentencial, mas pode sim impor ao magistrado um maior dever de cuidado ao julgar, evitando assim à displicência ou mesmo o desrespeito à legislação.

\section{PROTAGONISMO DO MAGISTRADO}

A responsabilidade social do magistrado decorre de sua função de Estado e nos Estados democráticos ele detém um importante papel. Portanto, o magistrado não está totalmente liberto quando exerce a sua função, ao contrário, está circunscrito a uma série de restrições à sua 
atuação, fato que torna importante o exame de outro fenômeno, que tem ganhado cada vez mais espaço no Judiciário nacional: o protagonismo judicial.

O termo 'protagonismo' é utilizado nos estudos literários para designar a personagem principal de uma narrativa ou de um drama, seja ela um herói ou um anti-herói. É ao redor da personagem principal, do protagonista, que se desenrola a trama, e também é de suas ações que, direta ou indiretamente, desencadeiam-se os acontecimentos (TRINDADE: 2012, p. 109). O cenário jurídico brasileiro apropriou-se desse termo, mantendo o seu significado, mas acrescendo o sufixo ismo (que pode indicar tanto a intoxicação de um agente, quanto um movimento social ou ideológico) e o adjetivo judicial, para então criar a expressão protagonismo judicial, utilizado para indicar um sistema em que a personagem principal é o magistrado (TRINDADE: 2012, p. 109).

Ao contrário de uma romance, em que o autor indica a personagem principal de acordo com a história por ele criada, no presente contexto o magistrado toma para si a responsabilidade de ser o protagonista dos atos, o herói da sociedade e o criador da história. Não é necessariamente a sociedade (que, por analogia, seria verdadeiramente a escritora dessa história) que delega esse papel, mas sim uma das tantas personagens que toma este papel. Essa característica não é imposta ao magistrado, mas este, valendo-se de uma centena de convergências, acaba por assumi-la. É importante, portanto, que se busque entender os motivos que levaram os magistrados a assumirem essa postura.

Primeiramente, tem-se a considerar que o velho jargão de que a lei é a expressão máxima da soberania de um povo já não se sustenta. Por esse sistema o magistrado não poderia exercer nenhuma influência sobre a Lei, deveria limitar-se apenas a aplicá-la. Essa concepção, advinda da denominada Escola da Exegese francesa do século XIX, foi combatida por dois fenômenos diferentes, mas que guardam certas semelhanças. A primeira delas é a crescente edição de textos legais mal redigidos e com péssimo conteúdo, o que permite a criação de amplos espaços para a interpretação. A segunda é a opção pela formação de comunidades supranacionais, que põem em cheque não apenas a clássica soberania dos Estados, mas também alguns de seus textos legais. O colapso da visão novecentista do direito, aliado às garantias dadas aos magistrados para que interpretem as leis, oferecidos tanto pelos textos legais imprecisos e abertos, como é o caso da Constituição Brasileira, quanto pela proliferação de tratados internacionais, trazem um ar de permissividade à atuação dos magistrados que se sentem não apenas libertos, mas também imbuídos de uma obrigação que constitucionalmente não lhes 
caberia, a de protagonistas de atos judiciais inovadores no mundo jurídico (GARAPON: 2001, p. 40).

O crescente fenômeno do protagonismo judicial tem posto em crise a própria separação entre as funções do Estado. Talvez uma de suas consequências mais expressivas seja a acentuada transferência do protagonismo do Poder Legislativo em direção à Justiça Constitucional, ao ponto de autores como Alexy falarem de uma 'onipotência dos Tribunais' (omnipotenz der Gerichte). Esse processo de deslocamento de poderes e de protagonismo dos magistrados pode ser considerado como uma severa lesão aos princípios democráticos (STRECK: 2013, p. 114):

\begin{abstract}
As decisões judiciais, dada a variação de entendimentos relativos ao livre convencimento, geralmente provocam a distribuição desigual de justiça para jurisdicionados, que experimentam conflitos semelhantes em suas vidas cotidianas. Tal situação, ainda que não afete internamente o campo jurídico brasileiro, não contribui para a credibilidade do Judiciário na nossa sociedade. A fragilidade do reconhecimento atribuído aos tribunais contribui para aumentar o afastamento entre o direito, a Justiça e a sociedade no Brasil. (MENDES: 2008, p. 197)
\end{abstract}

O magistrado não pode deixar de julgar um caso posto à sua apreciação sob a alegação de que existe alguma lacuna na lei ou mesmo que exista algum conflito entre leis vigentes, ou seja, mesmo nesses casos, o magistrado é obrigado a resolver o conflito. E mais, ao julgar, o magistrado é obrigado a fundamentar a sua decisão, removendo tais incompatibilidades e as contradições encontradas no sistema. Essa fundamentação deve ser clara, fazendo que com a sociedade a tome com válida e legítima, cumprindo assim a sua responsabilidade social (CYRILLO: 2007, p. 92). Nesse momento, os holofotes são necessariamente voltados ao magistrado, que deve sim resolver o caso, porém jamais impondo as suas concepções pessoais, mas sim aplicando ao vazio legislativo as premissas sociais mais abrangentes.

Como protagonista, o magistrado passa a ser o novo anjo da democracia, e toma para si um status privilegiado que expulsou os políticos. Ou seja, o magistrado inverte as posições na missão salvadora da democracia, colocando-se em posição de domínio e de intocado pela crítica popular. Para tanto, usa como combustível a própria crise e o descrédito dos demais Poderes. Dessa forma, a justiça cumpre a sua premissa de despolitizar a democracia (GARAPON: 2001, p. 74). Esse protagonismo dos magistrados não surge necessariamente da qualidade de seus serviços ou decorrem de seu cargo, mas sim da crise vivenciada pelas demais instancias públicas e pelo descrédito de seus representantes. 
Nessa posição de protagonista, o magistrado passa a usar o seu verdadeiro poder (jurídico, político e social) para satisfazer as vicissitudes que entende devidas por meio das suas decisões, as quais nem sempre conseguem expressar uma vontade verdadeiramente democrática. Um dos grandes problemas decorrentes desse protagonismo é a tomada de decisões que nada, ou quase nada, refletem as legislações democraticamente aprovadas pelo Legislativo. E mais do que isso, deixam, por sentirem-se intocados, de fundamentar de forma correta e coerente as suas decisões.

\begin{abstract}
Mais do que os virtuosismos cerebrais da dialética, os juízes fiam-se na sua sensibilidade moral e quando são obrigados a encher de argumentos jurídicos as razões das suas sentenças, consideram essa tarefa como um luxo de intelectuais desempregados, visto estarem convencidos de que, desde que aquela sua intima voz da consciência tenha falado, já não são precisos argumentos racionais. CALAMANDREI: 2013, p. 127)
\end{abstract}

Ao julgar, em tese (pois não basta julgar, é necessário também fundamentar de forma racional e substancial), o magistrado está efetivamente exercitando a sua função pública, agindo em nome do Estado e para o Estado, de forma a cumprir com a sua obrigação dentro da complexa engrenagem social, tendo como finalidade a manutenção e o desenvolvimento da soberania e da democracia. Ao decidir, o magistrado jamais poderá desqualificar as convicções de uma nação, pois fala em nome de seu povo, e jamais em seu próprio nome 9ALEXY: 2005, p. 41).

Não há duvida de que o magistrado pode ser visto como um exemplo, como o profissional encarregado de fazer justiça; e que também pode ser visto como o 'guardião das garantias constitucionais', como um cidadão atuante, como um aplicador ou como crítico das leis que aplica, ou ainda como uma pessoa capaz de resolver as iniquidades que a aplicação desidiosa poderia acarretar, ou simplesmente como o agente que pugna por melhoras dos sistemas jurídicos e sociais. Cada pessoa, ou grupos de pessoas, elege uma forma de ver o magistrado, mas o importante é entender que cada uma dessas visões nos conduz a uma forma diversa de ver a magistratura, as suas funções e a suas responsabilidades (BENETI: 2003, p. 09). Mas independentemente da forma que seja visto o magistrado, não há duvida de que a sua atuação está sim limitada tanto pela normas vigentes quanto pelos interesses da sociedade, último controlador da atividade dos magistrados.

Aqui se pode observar um paradoxo entre este protagonismo do magistrado e a sua responsabilidade social. Ao proferir a sua decisão, o magistrado deveria ter em mente a possibilidade de que seus familiares, amigos, leigos ou técnicos, pudessem compreendê-la Revista de Teorias da Justiça, da Decisão e da Argumentação Jurídical e-SSN: 2525-9644|Curitiba|v.2|n. 2|p.117-132| Jul/Dez. 2016. 
quando lida na integra em telejornais, ou transcrita em jornais ou revistas, sem qualquer isto lhe causasse qualquer tipo de constrangimento ou mesmo gerasse reprovação. Se, ao terminar de redigir a sentença, o magistrado imaginar ter conseguido alcançar este objetivo, poderá considerar o seu trabalho finalizado, e mais, estará diante de uma boa sentença, ainda que humildemente redigida, e destinada apenas a encerrar-se nos autos do processo, e permanecer pela eternidade nos arquivos judiciários, tendo para si apenas o orgulho do dever cumprido (BENETI: 2003, p. 114). A decisão não deve querer alcançar as paginas dos noticiários por ser diferente, inovadora, ou mesmo, que leve o magistrado a pronunciar-se em cadeia nacional, pois este não é o objetivo da sua função.

O mais intrigante nesse fenômeno é o fato de que ele não cresce por um mérito próprio dos magistrados, mas sim, por demérito das instituições políticas clássicas, gerado tanto pelo aumento do desinteresse da população pela política tradicional (ocasionado pela perda do espírito político), como também pelos constantes escândalos de corrupção que tomam a cena. Neste cenário, o magistrado é tido como um herói, imparcial e descompromissado partidariamente, sendo a sua atuação forma de compensar o déficit democrático nacional, e suas decisões surgem diante de uma necessidade de uma nova referência democrática simbólica, perdida ao longo dos anos. Do outro lado encontramos um Poder Legislativo e um Executivo enfraquecidos, sempre preocupados com as próximas eleições e com projeto de curto prazo, submissos à opinião pública e aos meios de comunicação. E, por fỉm, temos ainda a destacar, como causa deste protagonismo, a existência de uma população indiferente aos problemas nacionais, preocupados tão somente com as suas questões particulares, mas exigentes quanto à atuação das instituições públicas, sempre na expectativa de o político lhe fornece o que precisa (GARAPON: 2001, p. 48).

Posto tudo isso, o que resta claro é que o magistrado, ao julgar, não pode apenas invocar as sua própria moralidade particular, bem como, somente as ideias e virtudes da moralidade geral, mas também não deve desconsiderá-las por completo. Também não pode invocar suas visões religiosas ou filosóficas, nem suas, nem de outras pessoas. Devem sim trazer ao processo os parâmetros de política pública, decorrentes da própria sociedade, e que surgem de um entendimento razoável, ou seja, buscar uma resposta na razão pública para decidir casos complexos, que envolvam contradições ou vazios legislativos. Se estes parâmetros devem ser observados pela população em geral nas suas atitudes diárias, muito mais devem ser observado pelo magistrado do desempenho da sua função (RAWLS: 2000, p. 287). 


\section{A RESPONSABILIDADE SOCIAL, O PROTAGONISMO JUDICIAL E A DEMOCRACIA}

Não restam duvidas quanto à existência de uma profunda crise no processo de formação da legislação nacional, pois este já não consegue acompanhar a evolução da sociedade, seja diante das amarras impostas pelo processo de criação e a aprovação da lei (burocracia), seja pela ineficiência e incompetência de seus atores (vereadores, deputados e senadores), preocupados tão somente em garantirem-se nas próximas eleições. Tal crise estende-se ao Poder Executivo, que encontra-se politicamente preso a interesses políticos, e prossegue até o conturbado e superlotado Poder Judiciário, onde encontramos o magistrado, que, tomando para si o protagonismo das ações, quer representar a solução de todos estes problemas. Mas, mesmo diante desta crise, ainda resta uma grande incógnita, de complexa resposta: como alcançar uma real democracia?

Para que uma sociedade realmente seja democrática, é necessário que exista e seja respeitada a relação entre os Poderes, como também a criação de um espaço político limitado por regras claras e procedimentos pré-determinados, capazes de garantir um verdadeiro e livre espaço de participação e de discussão entre todos os cidadãos, bem como que a nação possa ser alcançada (de uma forma ou outra) pelas ações governamentais. Por fim, também é necessário que se encontre um equilíbrio nas ações, de forma que sejam atendidas às demandas públicas, decididas pela maior parte possível da população (seja de forma direta ou indireta) (LEAL: 2007, p. 37).

A criação destas regras (tanto materiais, quanto de procedimento), que são verdadeiros pressupostos da democracia, deve ser feita dentro de um sistema legislativo (Poder Legislativo), também constituído por processos e procedimento internos, igualmente democráticos (pelo menos em tese), criados a partir da manifestação da soberania popular, representado pelo voto dos integrantes do Poder Legislativo, democraticamente eleitos pela maioria da nação, e por tal motivo, legitimados pela própria sociedade. Tal consideração é importante quando constatamos que, contrariamente, as ordens provindas do Judiciário serão sempre impostas e nunca democraticamente discutidas (LEAL: 2007, p. 37). Aqui, o que se está tratando é do sistema de formulação das normas, e não de seu conteúdo, pois, nesse caso, seria necessária outra análise quanto ao conteúdo destas legislações e quanto aos interesses envolvidos, o que não se pretende neste trabalho.

E é justamente nesse contexto, de existência de pressupostos mínimos democráticos, é que ganha importância à discussão entre a responsabilidade social e o protagonismo dos Revista de Teorias da Justiça, da Decisão e da Argumentação Jurídical e-SSN: 2525-9644|Curitiba|v.2|n. 2|p.117-132| Jul/Dez. 2016. 
magistrados, pois, somente poderemos considerar a atuação do magistrado democrática, após um amplo debate interno, primeiramente do próprio magistrado que deve, antes de qualquer coisa, conhecer a si mesmo, entender verdadeiramente qual é a sua função dentro de uma sociedade democrática, e o caráter ideológico do seu trabalho, para só então transforma-se em operador jurídico orgânico, capaz de auxiliar no desenvolvimento da sociedade onde vive (ANDRADE: 1992, p. 41). E, em um segundo momento, com toda a população, de forma a efetivamente expor o seu pensamento a crítica pública, fazendo assim um controle externo de seus atos.

Aqui retomamos a expressão antes cunhada, de que a decisão do Poder Judiciária é sempre imposta, e a "norma" criada pela decisão não tem origem democrática, pois é tomada por uma pessoa (magistrado) ou grupo de pessoas (Órgãos Colegiados), a partir de interpretações pessoais quanto às normas democraticamente criadas, estas sim, decorrentes do devido processo de discussão e aprovação (mesmo que por meio da representação) e que devem sempre prevalecer.

Seguir o texto da lei é o único modo verdadeiro de honrar o pluralismo, a complexidade das relações sociais e a filosofia da possibilidade para utilizar expressão de Peter Haberle. Os resultados advindos do respeito aos limites semânticos e aos objetivos normativos implícitos podem agradar ou ferir o instinto de justiça tanto de conservadores quanto de progressistas: o comprometimento é com o texto da Constituição e das leis que passam no controle de constitucionalidade, e, especialmente diante de um documento jurídico supremo exaustivo como o nosso, nada garante que o texto trará, sempre, uma única visão de mundo predeterminada. $\mathrm{O}$ respeito à Constituição, em contextos democráticos, é o respeito ao texto legal elaborado pelos representantes do povo após debates públicos procedimentalmente regulados. (TORRANO: 2015, p. 257)

Não sobram duvidas quanto ao fato de que o magistrado, ao julgar casos difíceis, não resolvidos pela simples aplicação da legislação aos fatos narrados, deve ajustar os seus valores aos valores da coletividade, ou, aos valores de determinado círculo social envolvido na demanda, mesmo diante da resistência e das objeções levantas, como a alegação de que é praticamente impossível, em muitos casos, apontar com exatidão a valoração dada pela coletividade quanto aos direitos postos em discussão, ou mesmo, diante da baixa concretização destas valorações, o que enfraqueceria a fundamentação das decisões. Outro ponto de embate é o de qual caminho seguir quando estiverem em discussão juízos de valores distintos, ou mesmo, como se deve decidir dentro de círculos sociais muito determinados ou entre círculos sociais muito distintos. Nestes casos, cabe ao magistrado, a partir das premissas sociais já impostas (normas em sentido 
amplo), fundamentar a sua decisão, apontado quais as premissas que desestabilizaram a balança pra um lado ou para o outro e decidir de forma a contemplar os pressupostos que lhe são ofertados pela sociedade (ALEXY: 2005, p. 41).

Não há duvidas quanto à importância da atuação do magistrado para o desenvolvimento da democracia, bem como do seu importante papel ao decidir, de forma a contemplar a sua responsabilidade social. A discussão entre a sua atuação, o protagonismo do seu papel, a fundamentação das decisões, as suas responsabilidades jurídica, política e social e o desenvolvimento da democracia, não se encerra a somente com a fixação de critérios essenciais a decisão, mas sim, passa pela criteriosa análise do conteúdo das suas decisões e das consequências dela para a sociedade.

O raciocínio jurídico se expressa, primordialmente, no processo judicial, na motivação do juiz em dizer o direito do caso concreto, expressando as razões da sua decisão. Com efeito, ao decidir, deve o juiz interpretar o direito de forma razoável, ponderada e aceitável, a fim de transformar sua decisão em algo socialmente útil. (CYRILLO: 2007, p. 84)

Neste contexto, a fundamentação das decisões judiciais é a maior garantia de que efetivamente se faça a justiça, como também, uma importante forma de limitar o protagonismo dos magistrados e, em ultima análise, é o vetor do respeito e de desenvolvimento da democracia. Contudo, apenas nos casos em que esta fundamentação consiga reproduzir com exatidão o caminho lógico percorrido pelo magistrado, até chegar a sua decisão, será possível efetivamente exercer o controle social, pois, no caso de haver algum erro ou impropriedade na decisão, tanto a comunidade jurídica quanto a sociedade podem identificar em que ponto do caminho o magistrado se desorientou e desvirtuou a sua função (CALAMANDREI: 2013, p. 123). Também, somente dessa forma a sociedade poderá repassar ao magistrado as suas visões sobre a decisão, pontos em que concordam e pontos aos quais discordam, mas tudo dentro de uma discussão construtiva, capaz não só de orientar o magistrado, mas também, de promover a pacificação da sociedade.

E mais, a decisão também deve ser plenamente exequível, pois pouco adianta as partes uma sentença complexa e bela, ornada com citações em diversas línguas, acompanhada de teatrais passagens doutrinarias que pouco ou quase nada dizem as partes, pelo contrario, o que importa as partes é saber de forma clara o seu direito ou a sua obrigação (BENETI: 2013, p. 13). A sentença deve ser clara, exequível e inteligível, independentemente do grau de instrução ou de 
cultura das partes envolvidas, pois todos podem ter acesso a decisão e buscar ali a resposta mais adequada aos seus litígios:

A prestação jurisdicional não se exaure no escritório da sentença, muitas vezes, aliás, incompreensível para o jurisdicionado devido ao palavreado técnico. Só se realiza a prestação jurisdicional devido ao palavreado técnico. Só se realiza a prestação jurisdicionado devido ao palavreado técnico. Só se realia a prestação jurisdicional com a praticização do decidido, simples fato cuja beleza, para o juiz, é mais significativa do que arranjos florais de extratos de livros pinçados no afogadilho das últimas horas - que geralmente não provam cultura, mas simplesmente acesso a uma boa biblioteca, própria ou alheia. (BENETI: 2013, p. 13)

Ainda tem-se muito a evoluir na discussão sobre a atuação do Poder Judiciário, isto porque, grande parte das criticas realizadas, são de corte raso, limitando-se a discussão quanto ao positivismo ou ao ativismo jurídico, independente do seu conteúdo. É necessário ir mais fundo nesta discussão, de forma a questionar os fatores ideológicos que envolvem a prestação jurisdicional e de se descobrir a real função do Poder Judiciário, bem como, quem realmente está se beneficiando deste serviço. Em contrapartida, cresce cada vez mais a insatisfação da sociedade em relação ao Poder Judiciário, decorrente tanto do aumento da miséria, quanto da total ineficácia em ao menos tentar resolver os problemas sociais - promessa de um estado liberar. Estes fatores resultam no descrédito dos julgadores e no desprestigio ao próprio Poder Judiciário, porém tal fato parece não abalar o sistema, uma vez que o Poder Judiciário permanece firme em sua postura tradicional, mantendo uma estrutura elitizada (ANDRADE: 1992, p. 49). Esse modelo acaba relegando os socialmente vulneráveis para um segundo escalão de atenção, que os faz cair em uma espécie de limbo, tomado pela burocracia e pelo desinteresse dos seus servidores.

Verdadeiramente, o bom julgado é aquele que encontra um harmônico equilíbrio, expondo a sensibilidade do magistrado ao caso em discussão, mas também o tornando compreensível a todos que porventura venham a ler o seu escrito, sejam eles técnicos ou leigos. Mas também é necessário que consiga influenciar no retorno de credibilidade do magistrado, de forma a compor um ser difuso e etéreo, mas conhecido como a consciência jurídica da sociedade afetada pela decisão. Isto fará com que esta sociedade se solidarize a uma decisão efetivamente fundamentada (simpatia pelo julgado), ou crie repulsa, quando a decisão não for capaz de reproduzir os seus anseios (antipatia ao julgado) (BENETI: 2013, p. 114). Uma decisão que desperte a simpatia da comunidade, terá mais chances de efetivamente ser cumprida e de se 
perpetuar pela sociedade, agora, uma decisão que crie antipatia, até pode ser cumprida, mas certamente será objeto de tantos outros litígios, e retornará ao Poder Judiciário que terá, novamente, de manifestar-se sobre aquele decisão, tantas outras vezes, congestionando o sistema.

Posta a importância da discussão, não sobram duvidas que a justiça é um espaço privilegiado, onde os cidadãos podem exigir que se dê o devido respeito a democracia, uma vez que oferta ao cidadãos a possibilidade de demandar contra os seus governantes, exigindo que estes respeitem as premissas legais, especialmente as constitucionais, em pé de igualdade. Esta relação democrática é mais próxima do que a tradicional representação política, pois permite uma comunicação direta e individual entre o cidadão e o seu governo, sem que tenham intermediários, quase sempre comprometidos politicamente e que nem sempre conseguem defender os interesses dos seus representados (GARAPON: 2001, p. 49).

De outro lado, quando eleitos os magistrados como novos heróis da democracia, e a eles são submetidos todos os conflitos da vida moderna, a consequência é uma desvalorização do próprio papel do cidadão, enquanto agente político, o tornando um mero consumidor, um telespectador ou meramente um litigante. Este processo pode encaminhar a sociedade a ser dependente de uma nova ordem clerical de poder, agora comandada pelos magistrados, que podem, invariavelmente, confiscar a soberania para si, e distribuí-la somente aqueles mais hábeis na negociação e em conseguir os seus direitos (GARAPON: 2001, p. 62).

\section{CONCLUSÃO}

A responsabilidade social do magistrado configura-se na mais democrática forma de controle das ações do Poder Judiciário, pois não exige a existência de qualquer tipo de sanção na legislação, mas, ao contrário, expõem as razões de decidir a crítica da sociedade, seja ela leiga ou especializada, que, neste contexto, é capaz de exercer verdadeiramente um controle externo do Poder Judiciário. Neste ínterim, temos a própria sociedade exigindo do magistrado que atue de forma a correta e que tenha coerência nas suas decisões. Não há nenhum tipo de conflito entre o dever de prestação de contas e as liberdades decisórias do magistrado, ao contrário, há sim um silogismo muito interessante, que nos conduz a um Poder Judiciário forte, liberto e efetivamente democrático.

Nessa realidade, jamais poderia o magistrado tornar-se a protagonista dos atos sociais, por meio de suas decisões virtuosas e dotadas de rebuscadas construções de direitos, ao contrário, o magistrado deve entender-se como mais uma peça do quebra-cabeça social, tão importante quanto às demais, e só quando todos ocuparem o seu devido espaço é que a tarefa Revista de Teorias da Justiça, da Decisão e da Argumentação Jurídical e-SSN: 2525-9644|Curitiba|v.2|n. 2|p.117-132| Jul/Dez. 2016. 
poderá ser concluída, revelando a grande beleza da obra. Isto não quer dizer que o magistrado não deva exercer a sua função de forma livre, bem como, que a sua atuação deva ficar restrita somente a aplicar a lei, mas sim, que nos casos onde lhe for exigido uma atuação mais voluntariosa, deve o fazer sempre pensando na coletividade, nas suas vicissitudes e nas consequências de seus atos para além da relação processual. Jamais pode julgador imbuído tão somente em suas concepções pessoais e tentar, por meio da sentença impô-las como verdades absolutas a sociedade.

A responsabilidade social do magistrado é o maior balizador do seu protagonismo, isto porque deve sempre pautar a sua conduta, pois, do contrario, estará tomando para si o poder absoluto, que democraticamente foi distribuído entre os demais Poderes da Republica, de forma a garantir a continuidade da democracia e o desenvolvimento da sociedade. Jamais podemos perder de vista que uma lei, para vigorar, deve ser constitucional e democraticamente aprovada pelo Poder Legislativo, que é o extrato máximo de democracia dentro de um sistema representativo como é o brasileiro, e que ao ser desconsiderado pelo magistrado, este estará contrariando a vontade da maioria da população (pelo menos formalmente). Uma decisão democrática, tomada pelo Congresso Nacional jamais poderá ser simplesmente desconsiderada pelo magistrado, seja por qual argumento for. Neste contexto, podemos concluir que a responsabilidade social do magistrado é certamente uma ferramenta de proteção e promoção da democracia, dentro do sistema jurídico nacional, ao passo que o protagonismo do magistrado é certamente uma figura anômala, criada circunstancialmente dentro do próprio Poder Judiciário, como forma de 'legitimar' uma conduta mais pró-ativa e liberta, mas que o seu reflexo na sociedade ainda carece de importante esclarecimentos.

\section{REFERÊNCIAS}

AGUIAR JÚNIOR, Ruy Rosado de. O poder judiciário e a concretização das cláusulas gerais: limites e responsabilidades. Revista de Direito Renovar, Rio de Janeiro, v. 18, p. 11-19, setembro/dezembro de 2000. p. 12

ALEXY, Robert. Teoria da argumentação jurídica: a teoria do discurso racional como teoria da fundamentação jurídica. 2 ed. São Paulo: Landy Editora, 2005.

ANDRADE, Ledio Rose de. Juiz Alternativo e poder judiciário. Editora Acadêmica, São Paulo, 1.992.

BENETI, Sidnei Agostinho. Da conduta do juiz. $3^{\text {a }}$ ed. ver. São Paulo: Saraiva, 2003. 
CALAMANDREI, Piero. Eles, os juízes, vistos por nós, os advogados. São Paulo: Editora Pillares, 2013.

CAPPELLETTI, Mauro. Juízes Irresponsáveis? Sergio Antônio Fabris Editor: Porto Alegre, 1989

CYRILlO DA SILVA, Carolina Machado. Chaim Perelman: da argumentação à justiça: um retorno a Aristóteles. Porto Alegre: Linus Editores, 2007.

GARAPON, Antonie. O juiz e a democracia: o guardião das promessas. $2^{\text {a }}$ ed. Rio de Janeiro: Revan, 2001.

LEAL, Rogério Gesta. O Estado-Juiz na democracia contemporânea: uma perspectiva procedimentalista. Porto Alegre: Livraria do Advogado Ed., 2007

MENDES, Regina Lucia Teixeira. Dilemas da decisão judicial as representações dos juízes brasileiros sob o princípio do livre convencimento do juiz e outros principio correlatos. in Revista Ciências Sociais. Rio de Janeiro, 2008. Volume 14, nº. 1, páginas 191 - 207, disponível em: http://www.ugf.br/editora/pdf/ciencias_sociais/cs_v14_n1_artigo10.pdf

RAWLS, John. O liberalismo político. São Paulo: Editora Ática. 2.000

STRECK, Lenio Luiz. Jurisdição constitucional e decisão jurídica. $3^{\text {a }}$ edição. São Paulo: Editora Revista dos Tribunais, 2013

TORRANO, Bruno. Democracia e respeito à lei: entre o positivismo jurídico e pós-positivismo. Rio de Janeiro: Lumen Juris, 2.015

TRINDADE, André Karam. Garantismo versus neoconstitucionalismo: os desafios do protagonismo judicial em terrae brasilis. In: Garantismo, hermenêutica e (neo) constitucionalismo: um debate com Luigi Ferrajoli. Org. Luigi Ferrajoli, Lenio Luiz Streck e André Karam Trindade. Porto Alegre: Livraria do Advogado, 2012. p. 109 